\title{
Revised distribution, phenotypic variation, and conservation status of Liolaemus fittkaui (Squamata: Liolaemidae), a lizard endemic to the Andes of Central Bolivia
}

\author{
Octavio Jiménez-Robles ${ }^{1,2,3}$, Pablo Butron-Galvez ${ }^{4}$, René Carpio ${ }^{4}$, and Ignacio De la Riva ${ }^{1}$ \\ ${ }^{1}$ Department of Biodiversity and Evolutionary Biology, Museo Nacional de Ciencias Naturales, Consejo Superior de \\ Investigaciones Científicas, Madrid, Spain. E-mails: octavio.jimenez.robles@gmail.com, iriva@mncn.csic.es. \\ ${ }^{2}$ Department of Biogeography and Global Change, Museo Nacional de Ciencias Naturales, Consejo Superior de Investigaciones \\ Científicas, Madrid, Spain. \\ ${ }^{3}$ Department of Zoology, Universidad de Granada, Spain. \\ ${ }^{4}$ Centro de Biodiversidad y Genética, Facultad de Ciencias y Tecnología, Universidad Mayor de San Simón, Cochabamba, \\ Bolivia.
}

\begin{abstract}
Revised distribution, phenotypic variation and conservation status of Liolaemus fittkaui (Squamata: Liolaemidae), a lizard endemic to the Andes of Central Bolivia. The rare, endemic Bolivian lizard, Liolaemus fittkaui, was considered extinct at the locality of the paratypes. The species currently is catalogued as Vulnerable. The plausibility of the putative paratype locality is discussed, as it relates to the reported extinction event. Observations presented here evidence that the distribution of $L$. fittkaui is broader than has been reported, extending nearly $100 \mathrm{~km}$ along the highlands of the Cordillera de Tiraque (provinces of Chapare, Tiraque, and Carrasco). The species maintains populations in areas where its habitat is well conserved, some of them within the limits of the Carrasco National Park. This new information, following the IUCN criteria, indicates that the category of Vulnerable is adequate for the conservation status of $L$. fittkaui. Other records from Arque Province belong to L. variegatus and a species in the L. montanus series. Variation in ventral color pattern of males is described. Contrary to the whitish venter described originally, males seem to be polymorphic, having white, yellow, red, and intermediate combinations. The distribution of L. fittkaui and its ventral color morphs reflect a spatially fragmented range in which intraspecific evolution could result in marked genetic structure. The persistence of L. fittkaui and other endemisms confined to Andean highlands seems to depend on the preservation of puna grasslands, an ecosystem usually under-represented in conservation efforts.
\end{abstract}

Keywords: alpine grasslands, habitat, Liolaemus montanus series, polymorphism, wet puna.

Received 6 October 2015.

Accepted 2 February 2016.

Distributed June 2016. 


\begin{abstract}
Resumen
Revisión de la distribución, variación fenotípica y estado de conservación de Liolaemus fittkaui (Squamata: Liolaemidae), una lagartija endémica de los Andes de Bolivia Central. La rara lagartija Liolaemus fittkaui, endémica de Bolivia, fue considerada extinta en la localidad de los paratipos. Actualmente la especie está catalogada como Vulnerable. La credibilidad de la supuesta localidad de los paratipos es discutida, así como el evento de extinción reportado. Las observaciones presentadas aquí, ponen de manifiesto que la distribución de L.fittkaui es más amplia de lo que se conocía, extendiéndose cerca de $100 \mathrm{~km}$ a lo largo de las zonas altas de la Cordillera de Tiraque (provincias de Chapare, Tiraque, y Carrasco). La especie conserva poblaciones en zonas donde su hábitat está bien conservado; algunas de ellas dentro de los límites del Parque Nacional Carrasco. Esta nueva información, de acuerdo a los criterios de la UICN, indica que la categoría de Vulnerable es adecuada para el estado de conservación de L. fittkaui. Otros registros de la Provincia de Arque corresponden a $L$. variegatus y una especie de la serie de $L$. montanus. Se describe la variación en el patrón de coloración ventral de los machos. Respecto al vientre originalmente descrito como blancuzco, los machos parecen ser polimórficos, presentando blanco, amarillo, rojo y combinaciones intermedias. La distribución de L. fittkaui y sus morfos de coloración ventral, refleja una extensión espacialmente fragmentada en la que la evolución intraespecífica podría resultar en una marcada estructura genética. La persistencia de L. fittkaui y otros endemismos confinados a las zonas altas andinas parece depender de la preservación de los pajonales de la puna, un ecosistema usualmente poco representado en los esfuerzos de conservación.
\end{abstract}

Palabras clave: hábitat, herbazales alpinos, polimorfismo, puna húmeda, serie de Liolaemus montanus.

\begin{abstract}
Resumo
Revisão da distribuição geográfica, variação fenotípica e estado de conservação de Liolaemus fittkaui (Squamata: Liolaemidae), um lagarto endêmico dos Andes da Bolívia Central. O lagarto raro e endêmico da Bolívia Liolaemus fittkaui foi considerado extinto na localidade dos parátipos. Atualmente a espécie está classificada como Vulnerável. Discutimos a credibilidade da suposta localidade dos paratipos, assim como o evento de extinção relatado. As observações apresentadas evidenciam que a distribuição de L. fittkaui é mais ampla do que havia sido relatada, estendendo-se quase $100 \mathrm{~km}$ ao longo das regiões altas da Cordilheira de Tiraque (Províncias de Chapare, Tiraque e Carrasco). A espécie mantém populações em áreas em que seu habitat está bempreservado, algumas delas encontradas dentro dos limites do Parque Nacional Carrasco. Essa nova informação seguindo os critérios da IUCN, indica que a categoria Vulnerável é adequada para o estado de conservação de L. fittkaui. Outros registros da província Arque pertencem a Liolaemus variegatus e a uma espécie da série de L. montanus. Descrevemos a variação do padrão de coloração ventral dos machos; diferentemente do ventre esbranquiçado originalmente descrito, os machos parecem ser polimórficos, apresentando coloração branca, amarela, vermelha e combinações intermediárias. A distribuição de L. fittkaui e de suas formas de coloração ventral reflete uma distribuição espacialmente fragmentada na qual a evolução intraespecífica poderia resultar em uma estrutura genética marcada. A persistência de L. fittkaui e de outros endemismos confinados às regiões altas andinas parece depender da preservação dos campos da puna, um ecossistema geralmente sub-representado nos esforços de conservação.
\end{abstract}

Palavras-chave: campos alpinos, habitat, polimorfismo, puna úmida, série de Liolaemus montanus. 


\section{Introduction}

The Andes are one of the most biodiverse and threatened regions of the world (Myers et al. 2000), hosting high amounts of endemic plant and animal species (García-Moreno and Fjeldså 2000, Young et al. 2002, Hughes and Eastwood 2006). The higher species richness and sparse human population in lowland and mid-elevation Neotropical ecosystems have drawn the attention of conservationists, whereas the Andean highlands have received less attention. Bolivia is one of the lesser-known countries from a biodiversity standpoint, and consequently, the effects of anthropogenic disturbance on biodiversity are less documented. For thousands of years, agricultural anthropogenic activities (mostly crops and pastures) have dramatically modified the Bolivian Andean ecosystems (Ribera Arismedi 1992). Andean highland plant communities are remarkably degraded (Kessler 2002, Gareca et al. 2010). As a consequence, many vertebrates are considered endangered, and others have been totally or partially extirpated from these ecosystems (Ergueta and Morales 1996, Aguirre et al. 2009).

At the same time, little is known about the distribution and natural history of organisms within the Andean region of Bolivia (Tarifa et al. 2007). Undoubtedly there are new taxa to be found and described, including plants, invertebrates, and even vertebrates (De la Riva 2007). Moreover, many Andean species are endemic to particular mountain ranges, isolated by the complex topography of the area (Swenson et al. 2012, Anthelme et al. 2014).

Many Andean endemics are primarily known from their original descriptions. One of such species is the Bolivian lizard Liolaemus fittkaui Laurent, 1986. The holotype (ZSM 17/1983) was collected by Benno Marcus (1905, Bayern, Germany-1976, Cochabamba, Bolivia) without a date and with the imprecise locality of "Región de Cochabamba" (Laurent 1986). The four paratypes (UMMZ 68143, 172931; Laurent, 1986) together with nine specimens (UMMZ
224325-28, 172932-33; FML 16121-2; and MVZ 36458) (G. Schneider and C. Spencer, pers. comm.) were collected by F. B. Steinbach at "Tiraque, Depto. de Cochabamba", in April 1927 (Laurent 1986).

Owing to the scarce knowledge of this species, the conservation status of Liolaemus fittkaui was not evaluated in the first reviews of Bolivian vertebrates (Pacheco and Aparicio 1996, Aparicio 2003). It was declared as Critically Endangered by Embert (2007), because of its rarity and putative absence from protected areas. For years, searches for L. fittkaui in the environs of the village of Tiraque (3370 $\mathrm{m}$ a.s.1.) were conducted without success. The worldwide lizard extinction analysis by Sinervo et al. (2001) included this absence datum (as "Liolaemus fitzkauii [sic]" in Table S7A of that publication).

The distribution of Liolaemus fittkaui has been a mystery for years. To our knowledge, the first precise geographic records for L. fittkaui in the Cordillera de Tiraque were made in 2007, in wet puna grasslands above Koari-Quewiñacocha Lake, $4110 \mathrm{~m}$ a.s.l., Tiraque Province (locality 5 in Figure 1B), $13 \mathrm{~km}$ to the East of the village of the same name (T. Camacho-Badani \& O. Quinteros-Muñoz, pers. comm.; Aguayo et al. 2008). Because of this finding, L. fittkaui appeared as Vulnerable in the most recent review of conservation status of Bolivian reptiles (Aguayo et al. 2009).

Apart from this deficient information, none of the aforementioned conservation evaluations for the species included other previous records. In August 2000, T. Tarifa and E. Yensen collected and identified as Liolaemus fittkaui five lizards (CBF 2247-51) in Pusuq'huni (3700 m a.s.l.), Cerro Queñua Sandora, Arque Province, Cochabamba Department (question mark in Figure 1A) (Tarifa et al. 2007). This locality would increase the known range of L. fittkaui more than $80 \mathrm{~km}$ WSW of Tiraque. Specimens CBF 2247 and 2250 (but not the other three) were identified as L. fittkaui for morphological comparisons in the description of $L$. porosus (Abdala et al. 2013). 


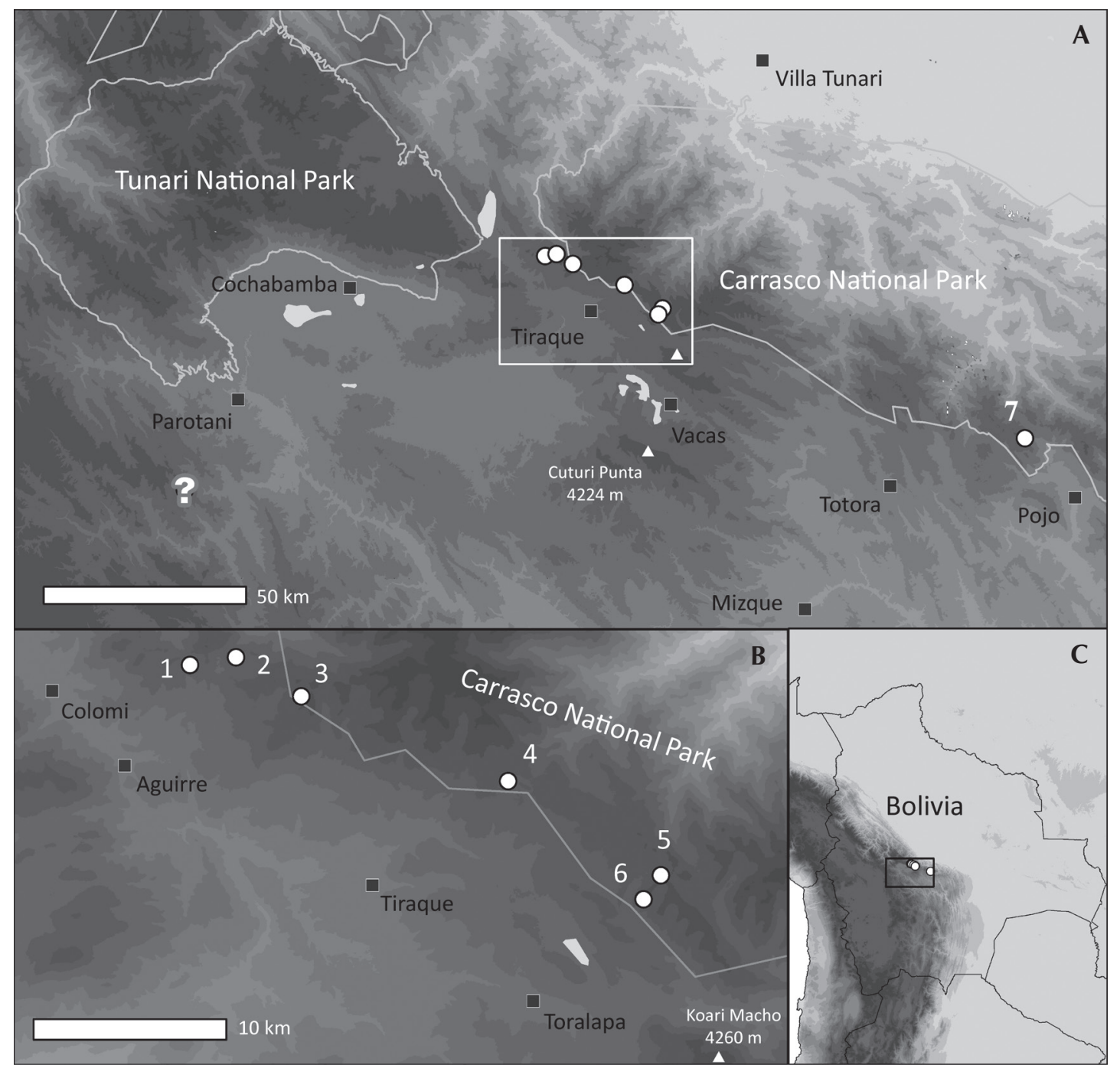

Figure 1. Maps showing the Liolaemus fittkaui records mentioned in the text: (A) mountains surrounding Cochabamba with Tunari and Carrasco National Parks; (B) southwestern border of the Carrasco National Park; and (C) area within Bolivia. Localities are: (1) Laguna de San Isidro, 3860 m a.s.I.; (2) Laguna Robada, 3870 m a.s.I.; (3) Cerro Rodeo, 4180 m a.s.I., Cotani Alto Highlands; (4) Laguna de Sallamani, 4050 m a.s.l.; (5) above Koari-Quewiñacocha, 4110 m a.s.I.; (6) above Quewiñacocha, 4105 m a.s.l.; (7) Pojo highlands, approximately $3800 \mathrm{~m}$ a.s.I.; and question mark, record of Liolaemus sp. (L. montanus series) and L. variegatus that were previously identified as L. fittkaui (Tarifa et al. 2007) in Pusuq'huni, 3700 m a.s.l., Cerro Queñua Sandora.

Given the intriguing distribution and conservation status of Liolaemus fittkaui, we review all the available information concerning obser- vations and the collections, providing new findings about the distribution and biology of this endemic Bolivian species. 


\section{Materials and Methods}

In November 2012 and September-December 2013 we explored several localities between 3700 and $4200 \mathrm{~m}$ a.s.l. in the provinces of Tiraque and Chapare, in the Cordillera de Tiraque, Department of Cochabamba. We registered every observation with a GPS and photographed the specimens. Some individuals died during short-term captivity to study their thermal ecology. These were fixed in $100 \%$ ethanol, preserved in $70 \%$ ethanol, and deposited in two collections-Colección Boliviana de Fauna (CBF), Museo Nacional de Historia Natural, La Paz, Bolivia, and Museo Nacional de Ciencias Naturales (MNCN), Madrid, Spain. The remaining individuals were released after data collection.

We compared the morphometry, scutellation, and coloration of our field observations, voucher specimens, along with those from Pusuq'huni with the diagnosis of the original description of Liolaemus fittkaui (Laurent 1986) and pictures of the holotype, paratypes, and specimens of $L$. fittkaui collected by F. B. Steinbach, as well as other species of the Andes of Central Bolivia that could be misidentified with L. fittkaui.

\section{Results}

In November 2012, I. De la Riva and P. A. Burrowes collected a male Liolaemus fittkaui (MNCN 46645) on a southern slope above Quewiñacocha Lake, Tiraque Province (4105 m a.s.l.), where puna grasslands had been partially converted into potato fields (Locality 6 in Figure 1B). Subsequently, we returned together with $T$. Camacho-Badani and O. Quinteros-Muñoz in September 2013 to the exact area where $L$. fittkaui had been observed by Aguayo et al. (2008) (Locality 5 in Figure 1B). We found $L$. fittkaui between 4090 and $4260 \mathrm{~m}$ a.s.l., documenting an increase in the known elevation range of the species. In the following days, we searched similar sites of the same mountain range, always paying special attention to areas with wet puna grasslands (sensu Navarro and Maldonado 2002). As a result, we found $L$. fittkaui at some additional localities, extending its known range $24 \mathrm{~km} \mathrm{WNW}$ of KoariQuewiñacocha (Localities 1-4, Figure 1B). These localities are: Laguna de San Isidro (3860 m a.s.l.; Figure 4A), and Laguna Robada (3870 $\mathrm{m}$ a.s.l.) in Chapare Province; and Cerro Rodeo (4180 m a.s.1.), and Laguna de Sallamani (4050 $\mathrm{m}$ a.s.l.) in Tiraque Province. Although most individuals were released after morphometric measures and photographs were taken, eight individuals were preserved: a female from Cerro Rodeo (MNCN 46646), and five males (CBF 4284-4287; MNCN 46647) and two females (CBF 4288; MNCN 46648) from Laguna Robada.

In January 2013 Jhony Salguero photographed a lizard (Figure 4B) about $3800 \mathrm{~m}$ a.s.l. in the highlands above Pojo, Carrasco Province, Cochabamba Department (Locality 7 in Figure 1A). The lizard later was identified as a female Liolaemus fittkaui, based on the morphology of dorsal and lateral scales, coloration pattern and morphometry. This is the most notable potential distributional expansion for L. fittkaui, increasing its known range by about $72 \mathrm{~km} \mathrm{E} \mathrm{Koari-}$ Quewiñacocha.

Examining Liolaemus fittkaui from the new localities, we found more phenotypic variation than originally described. The ventral coloration of the species was described as "whitish" (Laurent, 1986). This is true for all the females we observed, but not for living males. In the populations east of Tiraque (Sallamani and Koari-Quewiñacocha), most of the males have a white ground color ventrally, and a few are yellow or yellowish. However, west of Tiraque (Cerro Rodeo, Laguna Robada, and Laguna de San Isidro), most males have a red ventral ground color, whereas others have either yellow or white ventral ground colors, and their pairwise combinations (Figure 5). The five males from Laguna Robada (CBF 4284-4287; MNCN 46647) that were preserved in ethanol lost the red coloration within a year after their fixation. 
The five specimens from Pusuq'huni, Arque Province are significantly different than the original description of Liolaemus fitkaui, as well as the specimens that we observed (Table 1). Two (CBF 2249 and 2251) are Liolaemus variegatus (Aguilar-Kirigin, pers. comm.), a species that also occurs in Tiraque and other provinces of Cochabamba (Laurent 1984, Aguilar-Kirigin 2013). This species is easily distinguished from L. fittkaui by morphometry and color patterns (Table 1 and Figures 2 and 3). The other three specimens from the same locality (CBF 2247-2248 and 2250) lack particular diagnostic traits of L. fittkaui, such as the dorsal and lateral scales and the dorsal coloration pattern (Table 1 and Figures 2 and 3). The ventral coloration of specimens from Arque matches neither the original description nor our observations of L. fittkaui (i.e., whitish background in both sexes, with a conspicuous reticulated black pattern in males, which in females is absent or blurred). Laurent (1986) based his description on only one female. Among the females that we have seen in the field and the specimens of F. B. Steinbach in the UMMZ collection, none has such a conspicuous reticulate pattern as female CBF 2250 or a ventral pattern as dark as CBF 2248.
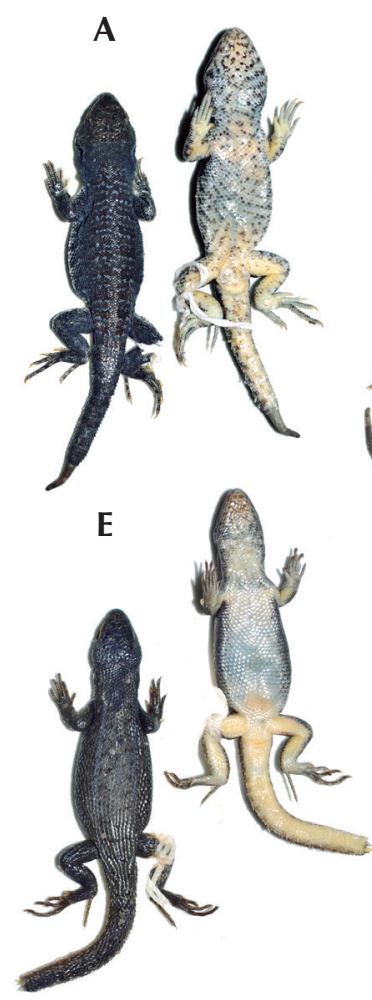
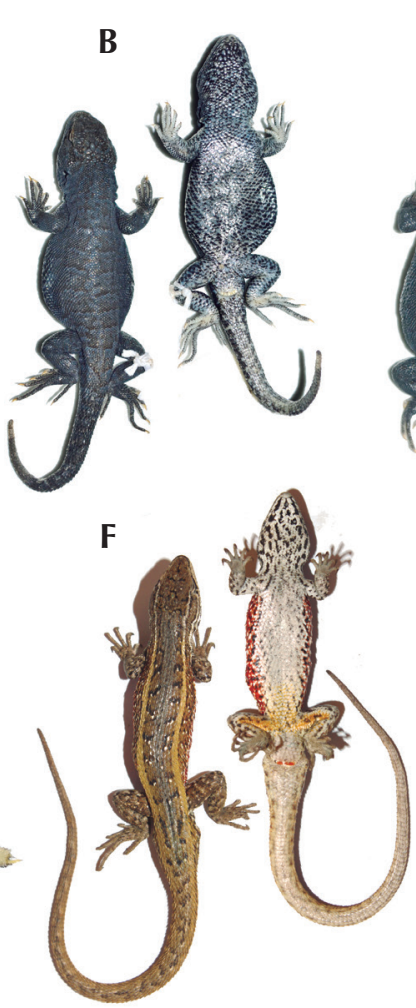

C
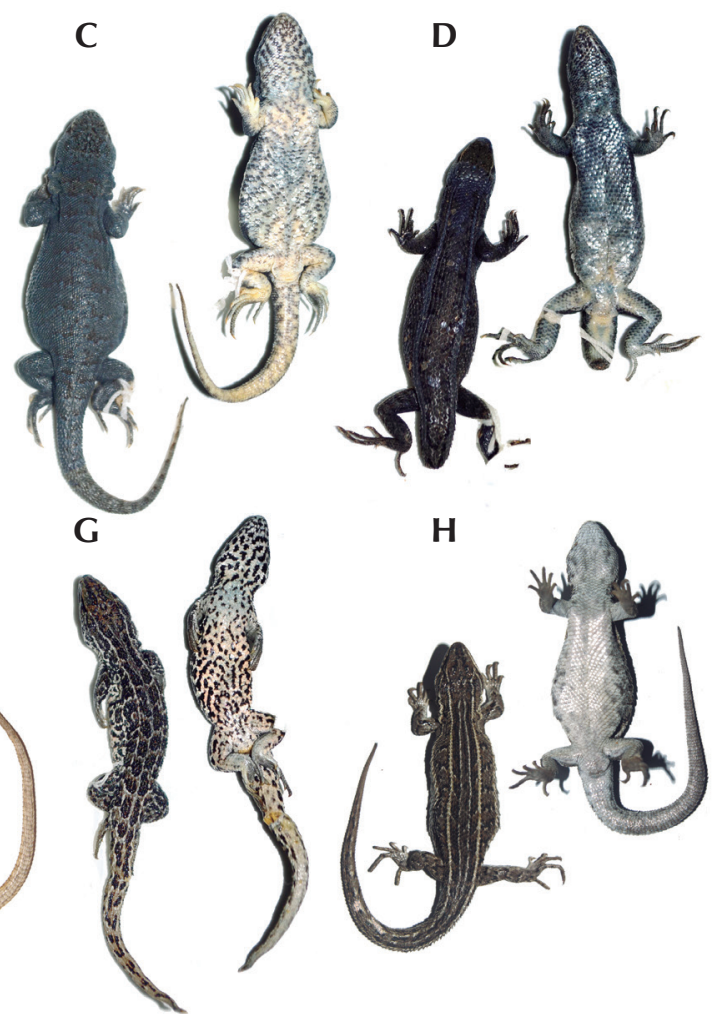

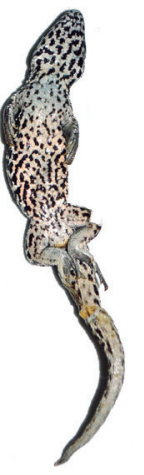

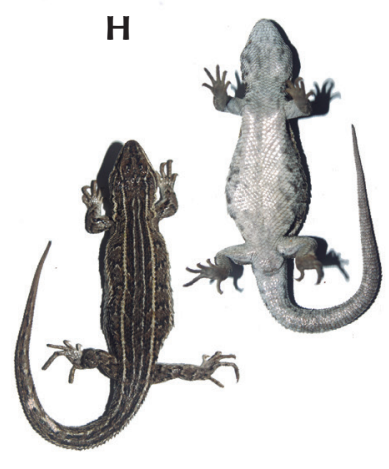

Figure 2. Specimens of Liolaemus collected by E. Yensen and T. Tarifa in Pusuq'huni, Queñua Sandora woodland, Palli Palli, Arque Province: Liolaemus sp. (A) male CBF 2247, (B) female CBF 2248, and (C) female CBF2250; Liolaemus variegatus (D) CBF 2249; and (E) CBF 2251. Other Liolaemus from the Cordillera de Tiraque: (F) male Liolaemus variegatus MNCN 46649 in life, from K'aspikancha, Tiraque Province; (G) male Liolaemus fittkaui MNCN 46647 from Laguna Robada, Chapare Province (its ventral coloration in life can be seen in Figure 5C); and (H) female Liolaemus fittkaui MNCN 46645 in life, from Cerro Rodeo, Tiraque Province. Photographs by Bruno Miranda (CBF-MNHN) and O. Jiménez-Robles. 

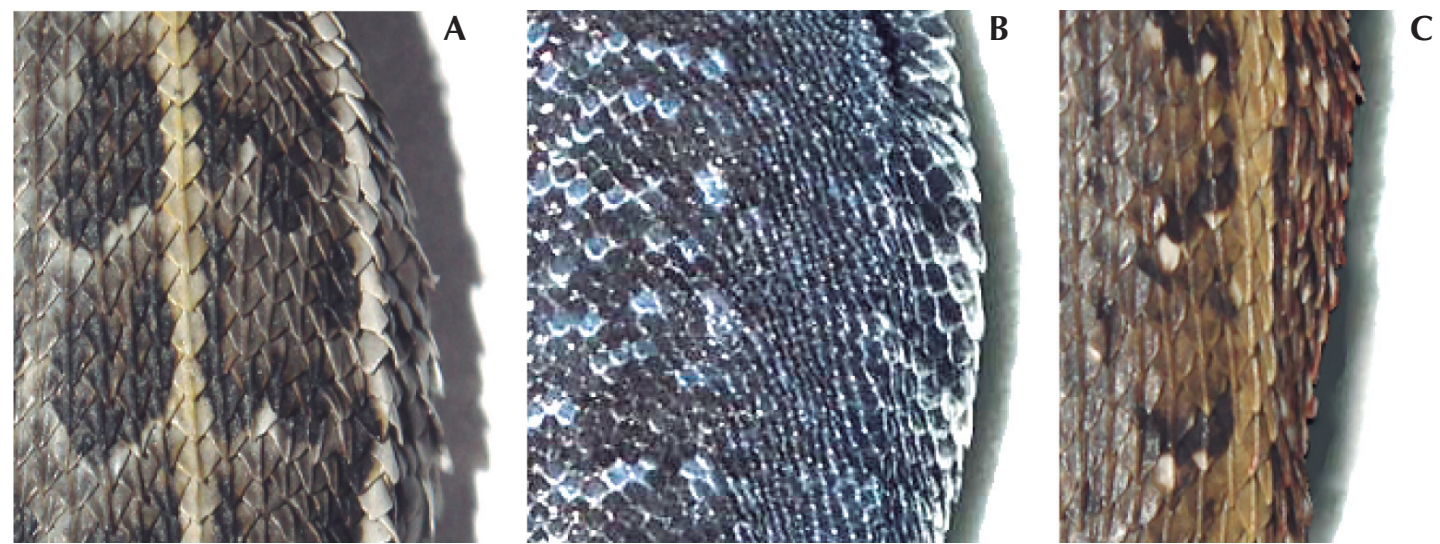

Figure 3. Dorsal and dorsolateral scales on the right part of midbody of (A) Liolaemus fittkaui female in life from Cerro Rodeo (not collected), (B) Liolaemus sp. CBF 2247 preserved, from Pusuq'huni, Arque Province, and (C) Liolaemus variegatus male MNCN 46649 in life, from K'aspikancha, Tiraque Province. Photographs by Bruno Miranda (CBF-MNHN) and O. Jiménez-Robles.

\section{Discussion}

These findings have extended the known range of Liolaemus fittkaui nearly $20 \mathrm{~km}$ NNW in the provinces of Chapare and Tiraque. The population near Pojo, is only represented by photographs and its identity needs to be confirmed; if it is L. fittkaui, the species would might have a discontinuous range along nearly $100 \mathrm{~km}$ in the highlands of the Cordillera de Tiraque (including the Province of Carrasco). Specimens CBF 2247-2248 and 2250 from Pusuq'huni, Arque Province, should not be considered L. fittkaui. Therefore, although likely within the L. montanus series (sensu Schulte et al. 2000, Lobo et al. 2010), the taxonomic status of these specimens needs to be clarified.

Currently, the known elevational distribution of Liolaemus fittkaui is from $3800-4260 \mathrm{~m}$ a.s.1., in the Cordillera de Tiraque, but further exploration of these mountains may reveal populations at greater or lesser elevations. Colomi Valley, at less than $3300 \mathrm{~m}$ a.s.l., may act as a dispersal barrier for L. fittkaui at present. Similarly, the mountains of Koari Macho (4260 m a.s.1.) and

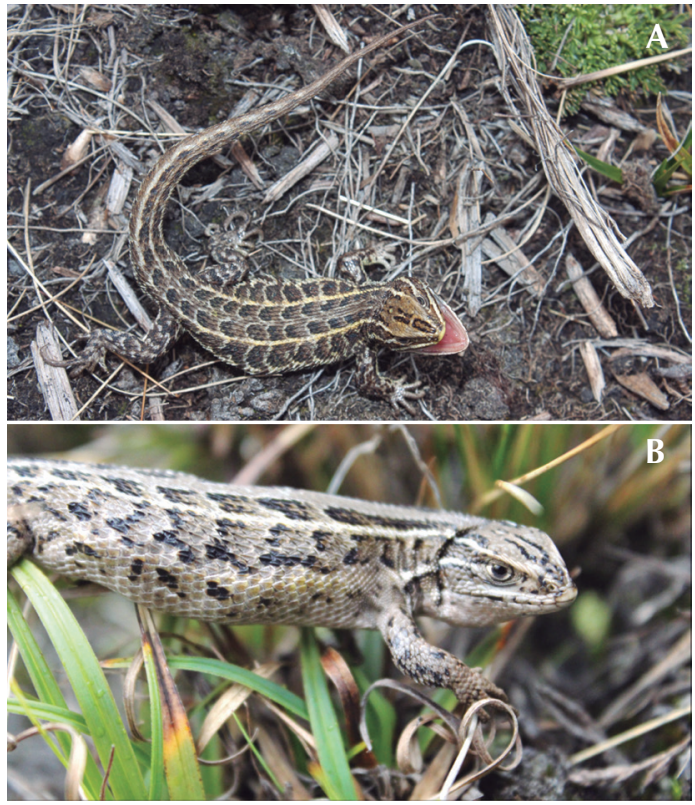

Figure 4. Liolaemus fittkaui found in both extremes of the Tiraque range: (A) male of Laguna San Isidro, Chapare Province $(3860 \mathrm{~m}$ a.s.I., westernmost known locality); (B) female in Pojo highlands, Carrasco Province (approximately 3800 m a.s.l., easternmost known locality). Photographs by O. Jiménez-Robles and J. Salguero (Inbox magazine). 

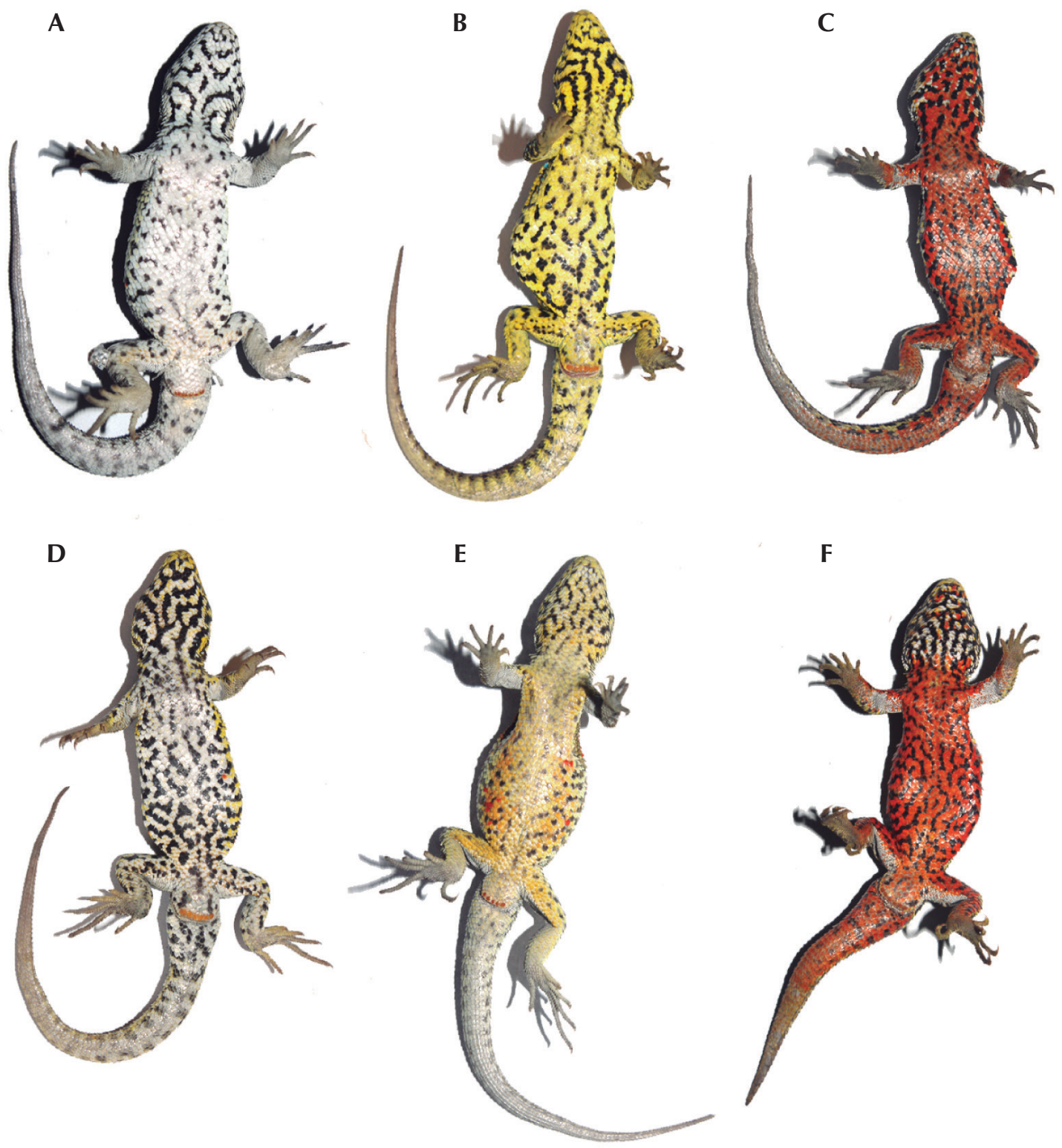

Figure 5. Ventral color variation of Liolaemus fittkaui males in life, along the species' known range in the Cordillera de Tiraque. The first row would represent single colors morphs: (A) white (Sallamani); (B) yellow (KoariQuewiñacocha); (C) red (Laguna Robada, MNCN 46647). The second row, combinations of them: (D) white-yellow (Koari-Quewiñacocha); (E) yellow-red (Cerro Rodeo); and (F) red-white (Cerro Rodeo). Another picture of the specimen MNCN 46647 after preservation can be seen in Figure 2G with most of the red pigmentation lost, less than two years after fixation. 
Table 1. Some differences among Liolaemus fittkaui, and the other two species which have been misidentified before as L. fittkaui: Liolaemus sp. from Pusuq'huni and L. variegatus.

\begin{tabular}{|c|c|c|c|}
\hline Traits & Liolaemus fittkaui & Liolaemus sp. from Pusuq'huni & Liolaemus variegatus \\
\hline Body size (mm) & $50-65$ & $56-63.6$ & $50-65$ \\
\hline $\begin{array}{l}\text { Relative tail } \\
\text { length (for non- } \\
\text { regenerated tails) }\end{array}$ & $\begin{array}{c}\text { Up to } 1.5 \text { and } 1.4 \text { of body } \\
\text { size in males and females, } \\
\text { respectively }\end{array}$ & Up to 1.04 of body size & $\begin{array}{l}\text { Up to double length or } 1.69 \\
\text { of body size in males and } \\
\text { females, respectively }\end{array}$ \\
\hline Dorsal scales & $\begin{array}{c}\text { Big, strongly keeled, } \\
\text { imbricated, triangular, and } \\
\text { acuminate }\end{array}$ & $\begin{array}{l}\text { Small, slightly keeled, almost } \\
\text { granular and smooth }\end{array}$ & $\begin{array}{c}\text { Big, strongly keeled, } \\
\text { imbricated, rhomboidal, and } \\
\text { acuminate }\end{array}$ \\
\hline Lateral scales & $\begin{array}{c}\text { Same size as dorsal scales, } \\
\text { imbricated, triangular, } \\
\text { acuminate and with keels that } \\
\text { disappear towards the ventral } \\
\text { region }\end{array}$ & $\begin{array}{c}\text { Smaller than dorsal scales, } \\
\text { granular }\end{array}$ & $\begin{array}{l}\text { Same size as dorsal scales, } \\
\text { imbricated, rhomboidal, } \\
\text { acuminate and with keels } \\
\text { that disappear towards the } \\
\text { ventral region }\end{array}$ \\
\hline Dorsal coloration & $\begin{array}{c}\text { (In life and in ethanol) } \\
\text { Two dorsal longitudinal rows } \\
\text { of dark chevrons posteriorly } \\
\text { bordered with white lines, in } \\
\text { males and most of females. } \\
\text { A pair of longitudinal dorsal } \\
\text { and dorsolateral stripes in } \\
\text { females and and most of } \\
\text { males } \\
\text { (In life) } \\
\text { Some males with red, blue } \\
\text { and yellow stripes and } \\
\text { scattered scales }\end{array}$ & $\begin{array}{c}\text { (In ethanol after their fixation } \\
\text { in formaline in 2000) } \\
\text { Dark grey with darker } \\
\text { transversal irregular stripes, } \\
\text { posteriorly bordered with } \\
\text { lighter bluish irregular } \\
\text { transversal stripes }\end{array}$ & $\begin{array}{c}\text { (In life and in ethanol) } \\
\text { Grey with two pairs of } \\
\text { darker longitudinal rows } \\
\text { (dorsal and dorsolateral) } \\
\text { with approximately a } \\
\text { dozen of black transversal } \\
\text { patches, posteriorly } \\
\text { bordered with two or three } \\
\text { white spots (generally } \\
\text { absent in females). Between } \\
\text { both pairs of rows of dark } \\
\text { patches, there are a pair of } \\
\text { grey dorsolateral stripes and } \\
\text { a dorsal stripe, all of them } \\
\text { grey }\end{array}$ \\
\hline $\begin{array}{l}\text { Ventral } \\
\text { coloration }\end{array}$ & $\begin{array}{c}\text { (In ethanol) } \\
\text { Whitish background in both } \\
\text { sexes, with a conspicuous } \\
\text { reticulated black pattern in } \\
\text { males, which in females is } \\
\text { absent or blurred. } \\
\text { (In life) } \\
\text { Blackground color can } \\
\text { be either white, yellow } \\
\text { or red, and intermediate } \\
\text { combinations }\end{array}$ & $\begin{array}{l}\text { (In ethanol after their fixation } \\
\text { in formaline in 2000) } \\
\text { Whitish background, with a } \\
\text { reticulated black pattern in } \\
\text { male CBF } 2247 \text { and female } \\
\text { CBF 2250. In female CBF } \\
2248 \text {, most of the scales have } \\
\text { black pigmentation, giving } \\
\text { the appearence of a dark grey } \\
\text { ventral surface }\end{array}$ & $\begin{array}{l}\text { (In ethanol and in life) } \\
\text { Whitish with a black } \\
\text { reticulated pattern, } \\
\text { conspicuous in the gorge } \\
\text { and blurred striped on the } \\
\text { belly }\end{array}$ \\
\hline
\end{tabular}

Cuturi Punta (4224 m a.s.l.) are only about $4 \mathrm{~km}$ and $24 \mathrm{~km}$, respectively, south of the Cordillera de Tiraque, and separated by small depressions (3600 $\mathrm{m}$ a.s.l. and $3400 \mathrm{~m}$ a.s.l., respectively).
Until further searches in neighboring mountains are conducted, we cannot discount the presence of L. fittkaui in other wet puna grasslands of Cochabamba Department. 
The paratype toponym "Tiraque, Depto. de Cochabamba" probably does not refer to the village of Tiraque but to the province of Tiraque. Thus, it may be inaccurate (as type locality). Unfortunately, it is too late to know whether the species was present in Tiraque in the past and, in that case, if climate warming might have caused its extinction (as hypothesized by Sinervo et al. 2010). However, given the habitat requirements of Liolaemus fittkaui, we doubt about its presence in the village of Tiraque (3370 $\mathrm{m}$ a.s.l), even in 1927.

The scant knowledge about the distribution of Liolaemus fittkaui seems to reflect a spatially fragmented range along the Cordillera de Tiraque. This distribution is typical of mountain endemics and usually creates opportunities for intraspecific evolution, resulting in marked patterns of genetic structure along the range of the species (Milá et al. 2013). In fact, the spatial differences we found in the occurrence of the different color morphs may reflect differences in the genetic flow among different areas (Calsbeek et al. 2010). Molecular studies might elucidate the degree of distinctiveness among populations along this complex topography.

The trimorphic coloration of male Liolaemus fittkaui may reflect an intra-population dynamic of reproductive strategies following a rockpaper-scissor game, as occurs in other species of lizards (Rand 1990, Sinervo and Lively 1996, Sinervo et al. 2001, Huyghe et al. 2007, Sinervo et al. 2007, Bastiaans et al. 2013, Galeotti et al. 2013). Other Liolaemus also are polymorphic with respect to ventral color (e.g., L. ornatus, $L$. orientalis; O. Jiménez-Robles, unpublished). We do not think that this polymorphism represents seasonal color variation, because we observed the range of phenotypic variation simultaneously. Further behavioral research is necessary to confirm the cause of these phenotypic polymorphisms in Liolaemus.

The Amazonian slopes of the Cordilleras de Tiraque and Cochabamba were identified as an exceptionally high center of endemism in the study of Swenson et al. (2012). Our data and other studies (Balderrama 2006, Tarifa et al. 2007) also reveal the biogeographic importance of the highlands of these mountain ranges for the conservation of several endemic organisms. To preserve this high diversity, we must map the distribution of endemic species, in addition to collecting more data on their ecology, habitat requirements, and population status.

In most cases, Liolaemus fittkaui was found in areas where wet puna grasslands (sensu Navarro and Maldonado 2002) were well conserved. The grasslands of Andean ecosystems (along with other elements) have received little attention from researchers and conservationists (Buytaert et al. 2011). In contrast, Polylepis forests, bogs, and wetlands have been the focus of several biodiversity and conservation studies in the Bolivian Andes, mainly dealing with plants, birds, and mammals (Balderrama 2006, Tarifa et al. 2007, Gareca et al. 2010, LozaHerrera et al. 2015). In some cases, puna grasslands have been regarded as the degradation stage of pristine Andean forests (Kessler 2002). However, other studies have demonstrated that forests did not cover the entire alpine region and that puna grasslands were also a fundamental part of Andean highlands climax ecosystems (Gareca et al. 2010). In this study, we provide evidence that puna grasslands by themselves contribute to the particular diversity of the Andes, being fundamental for endemic species such as L. fittkaui.

Organisms with limited dispersal ability such as arthropods, amphibians, and reptiles, have higher endemism rates than birds, mammals, and plants (Anthelme et al. 2014), but they are also understudied. Further inventories of these taxonomic groups in the puna grasslands of different Andean ranges may reveal more endemic organisms.

In addition to the conclusions of former conservation evaluations (Embert 2007, Aguayo et al. 2009), we note that some populations of Liolaemus fitkaui (Pojo Highlands, KoariQuewiñacocha, Sallamani and Cerro Rodeo) are in the Bolivian protected area network, within 
the Carrasco National Park (Figure 1B). However, the management of this area currently is focused on the preservation of the evergreen forests of the northern versants, and we suspect that the included puna grasslands probably are considered as a buffer area. Protection of endemic puna organisms, such as L. fittkaui, should appear in the park conservation programs as well.

Even inside the protected area network, the main threat to Liolaemus fittkaui is habitat loss, mostly resulting from the increase of agricultural activity (mainly potatoes), including pesticide use, overgrazing, and frequent grassland burning (Centro de Biodiversidad y Genética 2008, Aguayo et al. 2009). Fire is used to burn the "pajonal" tussocks, killing the organisms that find refuge in them. These fires can become uncontrolled and cause significant and extensive habitat degradation. After uncontrolled burning in an area such as Sallamani Lake (Figure 6), it was difficult to locate proper pristine wet puna grasslands, and consequently, L. fittkaui was found in low densities. Other areas with wellconserved habitat, such as Koari-Quewiñacocha, Cerro Rodeo, and Laguna Robada had relatively higher densities of L. fittkaui (O. Jiménez-
Robles, unpublished). However, some patches of these areas had been turned into small potato fields (Figure 6), and lizards scarcely could be found. These agricultural incursions are used for a short period, and then abandoned. Thus, preservation of the remnant extensions of pristine puna grasslands seems to be the most effective measure for the conservation of L. fittkaui and other endemic species.

The area of wet puna grasslands in the Cordillera de Tiraque is less than $500 \mathrm{~km}^{2}$. Currently there are fewer than 10 disjunct populations of Liolaemus fittkaui in a landscape blighted by recent destruction of wet puna grasslands; thus, extent and quality of habitat for L. fittkaui continues to decline. Therefore, we conclude that the category of Vulnerable [VU $\mathrm{B} 1 \mathrm{ab}(\mathrm{iii})+2 \mathrm{ab}(\mathrm{iii})]$ is adequate, according to the IUCN criteria (UICN 2012), for the conservation status of L. fittkaui.

We encourage the protection of these Andean highland ecosystems, increasing the areas already included in the national protected area network. The southern limits of the Carrasco National Park should be adjusted to include well-preserved patches of puna habitat. Other areas should be protected in the region to
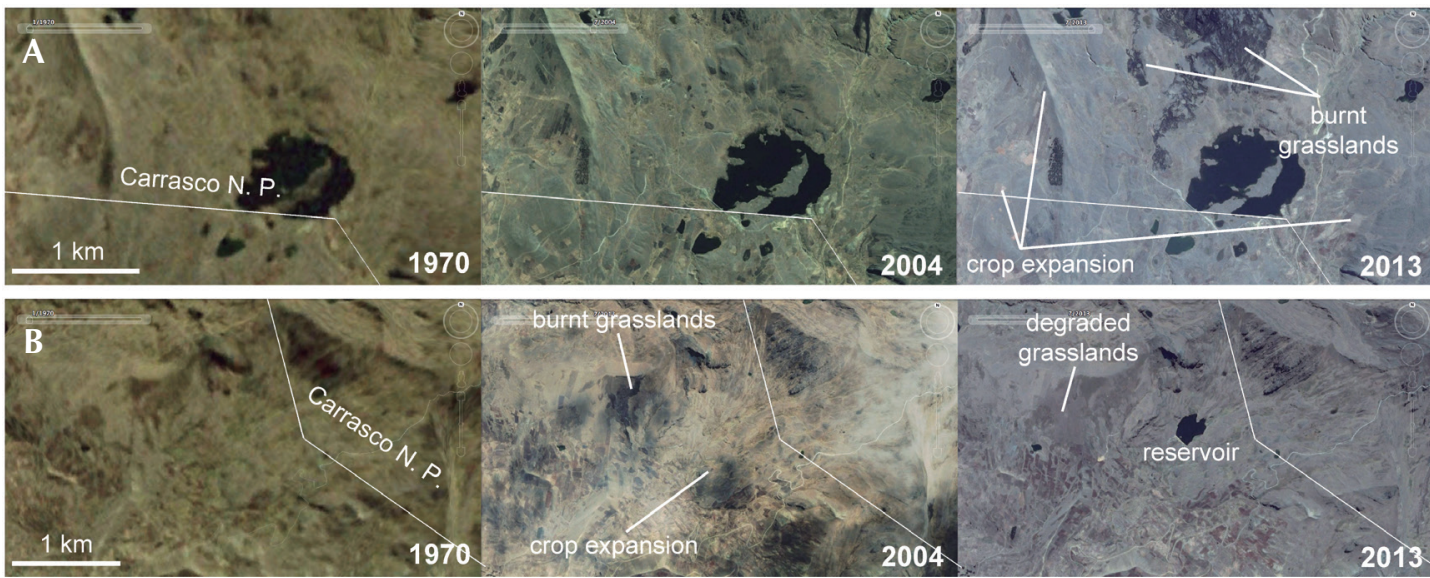

Figure 6. Habitat destruction and degradation in the areas of Sallamani (A) and Cerro Rodeo (B) observed in satellite images taken during 1970, 2004, and 2013. Source: GoogleEarth. 
safeguard their endemic organisms (Soria-Auza and Hennessey 2005). Given the high levels of human activity in the Bolivian Andean region, protection measures should be accompanied by outreach to create awareness in the indigenous population for the value of these ecosystems, regarding their services such as carbon storage and water supply (Farley et al. 2013), and the need to preserve their unique species. In the same way, certain endemic organisms could be periodically surveyed, in order to monitor population trends and prevent particular areas from habitat degradation.

\section{Acknowledgments}

We are grateful to Teresa Camacho-Badani, Oliver Quinteros-Muñoz, Noemí Goicoechea, and Jhony Salguero (Inbox magazine) for providing information about their field observations. James Aparicio (CBF-MNHN) provided information on collections and assistance with bureaucracy and sampling permits. Bruno Miranda photographed the specimens deposited in CBF-MNHN. Thanks to Cristian Abdala (FML), Greg Schneider (UMZM), and Carol Spencer (MVZ) for information about museum specimens. We are indebted to Kathrin Barboza and her family for help with logistics. Elsa Torrico and Vladimir Colque (Instituto Nacional de Innovación Agraria y Forestal) provided invaluable assistance, accommodation, and laboratories in the Estación Experimental de Toralapa. Linda Trueb, Robyn Womack and three anonymous reviewers provided helpful comments that considerably improved the manuscript. Marcos Peso-Fernández helped with abstract in Portuguese. Fieldwork was carried out under permits from Bolivian Ministry of Environment and Water (authorization VMA-DGBAP 1592/2012). This study was supported by Spanish Ministry of Economy and Competitiveness project CGL2011-30393 (Principal Investigator, I. De la Riva). Octavio Jiménez Robles was supported by a JAE-pre grant from the Spanish Scientific Research Council (CSIC).

\section{References}

Abdala, C. S., M. M. Paz, and R. V. Semhan. 2013. Nuevo Liolaemus (Iguania: Liolaemidae) con novedoso carácter morfológico, de la frontera entre Argentina y Chile. Revista de Biologia Tropical 61: 1563-1584.

Aguayo, R., O. Quinteros-Muñoz, and S. Quinteros. 2009. Liolaemus fittkaui. Pp. 269-270 in L. F. Aguirre, R. Aguayo, J. Balderrama, C. Cortez, and T. Tarifa (eds.), Libro Rojo de la Vida Silvestre de Vertebrados de Bolivia. La Paz. Ministeria de Medio Ambiente y Agua.

Aguayo, R., P. Vallejo, O. Quinteros, and F. Valdivia. 2008. Estudio de la diversidad de la herpetofauna en la subcuenca del río Jatún Mayu. Pp. 44-51 in Centro de Biodiversidad y Genética (ed.), Biodiversity Study in the Jatun Mayu River Watershed. Cochabamba. Faculty of Sciences and Technology, Universidad Mayor de San Simón.

Aguilar-Kirigin, A. J., J. Aparicio, and J. N. Ríos. 2013. Ampliación de la distribución geográfica de Liolaemus variegatus Laurent 1984 (Iguania: Liolaemidae) en Bolivia. Cuadernos de Herpetologia 27: 77-79.

Aguirre, L. F., D. A. Peñaranda, and O. Rocha. 2009. Evaluación del estado de conservación de los vertebrados de Bolivia. Pp. 19-24 in L. F. Aguirre, R. Aguayo, J. Balderrama, C. Cortez, and T. Tarifa (eds.), Libro Rojo de la Vida Silvestre de Vertebrados de Bolivia. La Paz. Ministeria de Medio Ambiente y Agua.

Anthelme, F., D. Jacobsen, P. Macek, R. I. Meneses, P. Moret, S. Beck, and O. Dangles. 2014. Biodiversity patterns and continental insularity in the tropical High Andes. Arctic, Antarctic, and Alpine Research 46: 811-828.

Aparicio, J. 2003. Reptiles. Pp. 55-68 in E. Flores and C. Miranda (eds.), Fauna Amenazada de Bolivia: :Animales Sin Futuro? La Paz. Ministerio de Desarrollo Sostenible.

Balderrama, J. A. 2006. Diversidad, endemismo y conservación de la ornitofauna del Parque Nacional Tunari (Cochabamba, Bolivia). Ecología en Bolivia 41: 149_ 170 .

Bastiaans, E., G. Morinaga, J. G. C. Gaytán, J. C. Marshall, and B. Sinervo. 2013. Male aggression varies with throat color in two distinct populations of the mesquite lizard. Behavioral Ecology 24: 968-981.

Buytaert, W., F. Cuesta-Camacho, and C. Tobón. 2011. Potential impacts of climate change on the environmental services of humid tropical alpine regions. Global Ecology and Biogeography 20: 19-33.

Calsbeek, R., L. Bonvini, and R. M. Cox. 2010. Geographic variation, frequency-dependent selection, and the 
maintenance of a female-limited polymorphism. Evolution 64: 116-125.

Centro de Biodiversidad y Genética. 2008. Biodiversity Study in the Jatun Mayu River Watershed. Cochabamba. Faculty of Sciences and Technology, Universidad Mayor de San Simón. 117 pp.

De la Riva, I. 2007. Bolivian frogs of the genus Phrynopus, with the description of twelve new species (Anura: Brachycephalidae). Herpetological Monographs 21: 241-277.

Embert, D. 2007. Distribution, diversity and conservation status of Bolivian reptiles. Unpublished M.Sc. Dissertation. Universität Bonn, Germany.

Ergueta, P. and C. Morales. 1996. Libro Rojo de los Vertebrados de Bolivia. La Paz. Centro de Datos para la Conservación, Offset Boliviana EDOBOL. 147 pp.

Farley, K. A., L. L. Bremer, C. P. Harden, and J. Hartsig. 2013. Changes in carbon storage under alternative land uses in biodiverse Andean grasslands: implications for payment for ecosystem services. Conservation Letters 6 : $21-27$.

Galeotti, P., R. Sacchi, D. Pellitteri-Rosa, A. Bellati, W. Cocca, A. Gentilli, S. Scali, and M. Fasola. 2013. Colour polymorphism and alternative breeding strategies: effects of parent's colour morph on fitness traits in the common wall lizard. Evolutionary Biology 40: 385-394.

García-Moreno, J. and J. Fjeldså. 2000. Chronology and mode of speciation in the Andean avifauna. Bonner Zoologische Monographien 46: 25-46.

Gareca, E. E., M. Hermy, J. Fjeldså, and O. Honnay. 2010. Polylepis woodland remnants as biodiversity islands in the Bolivian high Andes. Biodiversity and Conservation 19: 3327-3346.

Hughes, C. and R. Eastwood. 2006. Island radiation on a continental scale: exceptional rates of plant diversification after uplift of the Andes. Proceedings of the National Academy of Sciences 103: 10334-10339.

Huyghe, K., B. Vanhooydonck, A. Herrel, Z. Tadić, and R. Van Damme. 2007. Morphology, performance, behavior and ecology of three color morphs in males of the lizard Podarcis melisellensis. Integrative and Comparative Biology 47: 211-220.

Kessler, M. 2002. The "Polylepis problem": where do we stand? Ecotropica 8: 97-110.

Laurent, R. F. 1984. Tres especies nuevas del género Liolaemus (Reptilia, Iguanidae). Acta Zoologica Lilloana 37: 273-299.

Laurent, R. F. 1986. Descripciones de nuevos Iguanidae del género Liolaemus. Acta Zoologica Lilloana 38: 87-105.
Lobo, F., R. E. Espinoza, and S. Quinteros. 2010. A critical review and systematic discussion of recent classification proposals for liolaemid lizards. Zootaxa 2549: 1-30.

Loza-Herrera, S., R. I. Meneses, and F. Anthelme. 2015. Comunidades vegetales de los bofedales de la Cordillera Real (Bolivia) bajo el calentamiento global. Ecología en Bolivia 50: 39-56.

Milá, B., Y. Surget-Groba, B. Heulin, A. Gosá, and P. Fitze. 2013. Multilocus phylogeography of the common lizard Zootoca vivipara at the Ibero-Pyrenean suture zone reveals lowland barriers and high-elevation introgression. BMC Evolutionary Biology 13: 192-206.

Myers, N., R. A. Mittermeier, C. G. Mittermeier, G. A. B. Fonseca, and J. Kent. 2000. Biodiversity hotspots for conservation priorities. Nature 403: 853-858.

Navarro, G. and M. Maldonado. 2002. Vegetación y Unidades Biogeográficas de Bolivia. Cochabamba. Centro de Ecología Simón I. Patiño. 500 pp.

Pacheco, L. and J. Aparicio. 1996. Reptiles. Pp. 73-93 in P. Ergueta and C. Morales (eds.), Libro Rojo de los Vertebrados de Bolivia. La Paz. Centro de Datos para la Conservación, Offset Boliviana EDOBOL.

Rand, M. S. 1990. Polymorphic sexual coloration in the lizard Sceloporus undulatus erythrocheilus. American Midland Naturalist 124: 352-359.

Ribera Arismedi, M. 1992. Regiones ecológicas. Pp 9-71 in M. Marconi (ed.), Conservación de la Diversidad Biológica en Bolivia. La Paz. Centro de Datos para la Conservación.

Schulte, J. A., J. R. Macey, R. E. Espinoza, and A. Larson. 2000. Phylogenetic relationships in the iguanid lizard genus Liolaemus: multiple origins of viviparous reproduction and evidence for recurring Andean vicariance and dispersal. Biological Journal of the Linnean Society 69: 75-102.

Sinervo, B. and C. M. Lively. 1996. The rock-paper-scissors game and the evolution of alternative male strategies. Nature 380: 240-243.

Sinervo, B., C. Bleay, and C. Adamopoulou. 2001. Social causes of correlational selection and the resolution of a heritable throat color polymorphism in a lizard. Evolution 55: 2040-2052.

Sinervo, B., B. Heulin, Y. Surget-Groba, J. Clobert, D. B. Miles, A. Corl, A. Chaine, and A. Davis. 2007. Models of density-dependent genic selection and a new rockpaper-scissors social system. The American Naturalist 170: 663-680. 
Sinervo, B., F. M. de la Cruz, D. B. Miles, B. Heulin, E. Bastiaans, M. Villagrán-Santa Cruz, R. Lara-Resendiz, N. Martínez-Méndez, M. L. Calderón-Espinosa, R. N. Meza-Lázaro, H. Gadsden, L. J. Ávila, M. Morando, I. J. De la Riva, P. V. Sepúlveda, C. F. D. Rocha, N. Ibargüengoytia, C. Aguilar Puntriano, M. Massot, V. Lepetz, T. A. Oksanen, D. G. Chapple, A. M. Bauer, W. R. Branch, J. Clobert, and J. W. Sites Jr. 2010. Erosion of lizard diversity by climate change and altered thermal niches. Science 328: 894-899.

Soria-Auza, R. W. and B. Hennessey. 2005. Áreas importantes para la conservación de las aves en Bolivia. Pp. 57-116 in C. Devenish, D. F. Díaz-Fernández, R. P. Clay, I. Davidson, and I. Yépez-Zabala (eds.), Áreas Importantes para la Conservación de las Aves en los Andes Tropicales: Sitios Prioritarios para la Conservación de la Biodiversidad. Quito. BirdLife International \& Conservation International.

Swenson, J. J., B. E. Young, S. Beck, P. Comer, J. H. Córdova, J. Dyson, D. Embert, F. Encarnación, W.
Ferreira, I. Franke, D. Grossman, P. Hernandez, S. K. Herzog, C. Josse, G. Navarro, V. Pacheco, B. A. Stein, M. Timaná, A. Tovar, C. Tovar, J. Vargas, and C. M. Zambrana-Torrelio. 2012. Plant and animal endemism in the eastern Andean slope: challenges to conservation. BMC Ecology 12: 1-18.

Tarifa, T., J. Aparicio, and E. Yensen. 2007. Mammals, amphibians, and reptiles of the Bolivian High Andes: an initial comparison of diversity patterns in Polylepis woodlands. Pp. 241-274 in D. A. Kelt, E. P. Lessa, J. Salazar-Bravo, and J. L. Patton (eds.), The Quintessential Naturalist: Honoring the Life and Legacy of Oliver P. Pearson.Berckeley and Los Angeles. University of California Press, publications in Zoology 134.

Young, K. R., C. U. Ulloa, J. L. Luteyn, and S. Knapp. 2002. Plant evolution and endemism in Andean South America: an introduction. Botanical Review 68: 4-21.

Editor: Teresa C. S. Ávila Pires 